\title{
SIMBOL TUMBUHAN DALAM PANTUN MELAYU BINGKISAN PERMATA
}

\author{
Symbols of Plants in Pantun Melayu Bingkisan Permata \\ Eizah Mat Hussain \\ eizah@um.edu.my \\ Nurhamizah Hashim \\ aaee@um.edu.my \\ Nur Yuhanis Mohd Nasir \\ yuhanis83@um.edu.my \\ Universiti Malaya
}

\begin{abstract}
ABSTRAK
Pantun merupakan satu khazanah bangsa yang mempunyai nilai yang amat tinggi dalam kalangan masyarakat Melayu. Penyusunan pantun yang diolah dengan rapi dan disusun indah mengandungi seribu satu maksud yang amat mendalam, yang menjadi wadah dalam menyampaikan nasihat, sindiran, gurauan dan luahan perasaan. Dalam penciptaan pantun, masyarakat Melayu akan menggunakan simbol-simbol yang berada di sekeliling mereka. Salah satu simbol yang sering digunakan oleh masyarakat Melayu ialah simbol alam, iaitu tumbuhan yang merupakan unsur terpenting dalam binaan pantun. Salah satu prinsip estetika sastera Melayu oleh Muhammad Haji Salleh, iaitu 'dunia luas yang dipadatkan' digunakan untuk membincangkan simbol tumbuhan pertanian dalam pantun. Oleh yang demikian, objektif makalah ini untuk melihat sejauh mana prinsip 'dunia luas yang dipadatkan' sesuai diaplikasikan dalam menghuraikan makna tersirat daripada simbol tumbuhan pertanian dalam pantun. Selain itu, tujuan makalah untuk menganalisis simbol tumbuhan dalam pantun. Buku Pantun Melayu Bingkisan Permata (2007) yang diselenggarakan oleh Harun Mat Piah terbitan Yayasan Karyawan telah dipilih sebagai bahan kajian. Dapat kajian mendapati masyarakat Melayu mengungkapkan simbol tumbuhan yang terpilih dalam pantun dikaitkan persamaan dengan kelakukan manusia.
\end{abstract}

Kata kunci: pantun; simbol; dunia luas yang dipadatkan; tumbuhan pertanian; sayur-sayuran; buah-buahan.

\begin{abstract}
Pantun which is a type of Malay traditional poem is an invaluable Malay heritage. The writings of pantun were neatly crafted in sequences and beautifully arranged to embed meaningful messages which were used to convey advice, sarcasm, humors and feelings. The Malays used symbols which were present in their surroundings to write pantun. Nature is one of the common symbols used, especially plants which evidently present as an important element in constructing a verse. One of Malay literature aesthetical principle by Muhammad Haji Salleh which is about the 'compression of the big world' is used to discuss symbols of agricultural plants in pantun. The objective of this article is to see how far the principle of compressed world is suitable to be applied in describing hidden meanings from agricultural plants symbols in pantun. Besides, the purpose of this paper is to analyze from agricultural plants symbols in pantun. The book titled Pantun Melayu Bingkisan Permata (2007) arranged by Harun Mat Piah which was published by Yayasan Karyawan is used as adata. This study found that Malay community expressed selected symbols of plant in pantun and relate the symbols with human's behaviours.
\end{abstract}

Keywords: pantun; symbo;, 'compression of the big world'; agricultural plants; vegetables; fruit 


\section{PENGENALAN}

Pantun merupakan salah satu bentuk puisi Melayu lama yang diwarisi sejak zaman lampau dan masih kekal digunakan sehingga kini. Menurut Za'ba (1965, p. 218-219) pantun merupakan karangan berangkap (puisi) kepunyaan masyarakat Melayu lama dan digunakan di kampung-kampung untuk menggambarkan fikiran hiba, sayu dan warna perasaan yang indah-indah seperti hal ehwal berkasih sayang dan pujuk rayu yang lemah lembut antara pasangan kekasih.

Menurut Brandsetter (1955), perkataan 'pantun' berasal daripada akar kata tun yang terdapat juga dalam Bahasa Jawa Kuno, iaitu tuntun, dan dalam Bahasa Tagalog disebut tonton yang diucapkan dalam aturan yang tertentu. Dalam Bahasa Sunda, pantun bermaksud satu cerita panjang berirama yang dinyanyikan dengan iringan muzik. Dalam masyarakat Melayu pula, pantun bererti kuantrain, iaitu puisi yang tersusun dalam struktur empat baris serangkap. Ringkasnya, akar kata tun dalam bahasa Nusantara merujuk kepada sesuatu bentuk atau cara yang teratur dalam melahirkan sesuatu maksud atau fikiran (Amat Juhari Moain, 2008, p. 2).

Omarudin Haji Asha'ri dalam bukunya Kajian Pantun Melayu (1961), mengkategorikan pantun kepada dua bahagian, iaitu pembayang maksud dan maksud pantun. Pada pembayang maksud biasanya aspek tumbuh-tumbuhan dan alam digunakan. Menurut beliau, manusia mempunyai kebolehan semula jadi bagi mengambarkan alam dan kejadian yang berlaku dalam persekitaran. Bahagian kedua, rangkap maksud pantun lazimnya penuh dengan sindiran dan makna untuk manusia sebagai peringatan.

Unsur alam yang digunakan dalam pembayang atau maksud pantun wujud di sekitar kehidupan masyarakat Melayu. Satu unsur yang seringkali digunakan ialah tumbuh-tumbuhan. Hal ini disebabkan hubungan akrab manusia dengan alam pertanian yang dijadikan sebagai sumber rezeki. Rene Daillie (2002, p. 6) menyimpulkan bahawa pantun Melayu itu suatu intisari kehidupan dan alam yang diibaratkan sebagai butiran pasir. Menurut beliau, dalam pantun tersirat segala elemen kehidupan manusia Melayu termasuklah tentang tanah, rumah, kebun, sawah padi, sungai, laut, hutan, tumbuh-tumbuhan, buahbuahan, binatang, burung, ikan, dan pelbagai perkara kecil yang digunakan dalam kehidupan seharian. Dalam kajian ini, beliau menyatakan masyarakat Melayu mempunyai hubungan yang akrab dengan alam sekeliling dan memiliki ikatan yang harmoni dengan alam. Hal ini diperkukuhkan lagi dengan tulisan beliau, iaitu:

"This brief poem is an epitome of life and a universe in a grain of sand.It carries within itself all the element of the Malay man's life: his land, his house, his garden, his paddy field, the river, the sea or the forest",

(Rene Daillie, 2006, p. 10)

Proses penciptaan pantun banyak dipengaruhi oleh kemampuan pemikiran dan pengalaman hidup masyarakat Melayu yang sentiasa berinteraksi dengan alam sekitar. Oleh itu, masyarakat Melayu telah memilih simbol-simbol dari alam yang kemudian diunngkapkan dalam pantun yang mempunyai makna yang tersirat dan tersurat yang hendak disampaikan. Hal ini kerana simbol merupakan satu unsur bahasa yang penting dalam menyampaikan maksud pantun kepada khalayak pembaca. Makna simbol itu tersembunyi dalam kata atau ungkapan yang mempunyai makna tersurat. Penggunaan simbol-simbol tertentu mewakili sesuatu makna atau idea sebenarnya bukanlah dilakukan secara sesuka hati, bahkan keadaan ini mempamerkan kelebihan masyarakat Melayu yang kaya dengan bahan-bahan kiasan yang penuh dengan unsur-unsur simbolik. Tuner (1966), mendefinisikan simbol sebagai objek, aktiviti, perhubungan dan ruang dalam situasi upacara adat istiadat, manakala Muhammad Afandi Yahya (1995) menyatakan simbol yang didapati adalah hasil daripada pengaruh sejarah, kehidupan seharian, kepercayaan agama dan alam sekitar.

Oleh yang demikian, melalui simbol dalam pantun terungkap pelbagai falsafah dan pemikiran masyarakat Melayu. Simbol dalam pantun juga memainkan peranan penting dalam kehidupan masyarakat Melayu tradisional. Pemikiran, keinginan, luahan hati, perasaan dan pengalaman hidup digambarkan serta disalurkan melalui pantun. Melalui simbol yang terdapat dalam pantun, terpancar minda masyarakat Melayu yang penuh dengan pemikiran dan nilai yang tinggi yang diambil daripada pengamatan terhadap alam terutamanya alam tumbuhan pertanian. 


\section{METODOLOGI}

Kajian ini menganalisis dan mengkaji simbol tumbuhan pertanian yang diungkapkan dalam pantun Melayu. Kajian ini merupakan penelitian terhadap konsep dan menggunakan kaedah kajian pustaka. Bahan kajian diperoleh daripada koleksi buku Pantun Melayu Bingkisan Permata (2007) yang diselenggarakan oleh Harun Mat Piah dan diterbitkan oleh Yayasan Karyawan. Pantun Melayu Bingkisan Permata dipilih kerana pantun yang dimuatkan merupakan hasil dapatan dan himpunan data dari sumbersumber perbahanan yang banyak serta terpilih. Antara sumber bahan ialah himpunan dan juga kumpulan, antologi, koleksi pantun yang diterbitkan dan tidak diterbitkan, koleksi peribadi pengarang, hasil kajian penulis dan pengkaji yang terlibat dalam penyelidikan dan juga petikan dari karya-karya hikayat. Malah Pantun Melayu Bingkisan Permata ini juga memasukkan pantun-pantun terpilih dari Brunei.

Oleh sebab keistimewaan inilah, Pantun Melayu Bingkisan Permata (2007) telah dipilih sebagai bahan kajian dalam perbincangan ini. Objektif makalah ini untuk melihat sejauh mana prinsip dunia luas yang dipadatkan sesuai diaplikasikan dalam menghuraikan makna tersirat dan tersurat daripada simbol tumbuhan pertanian dalam pantun yang memperlihatkan keindahan pantun. Selain itu, kajian ini bertujuan menganalisis simbol tumbuhan yang digunakan dalam pantun Melayu.

Pantun Melayu merupakan hak cipta masyarakat Melayu, dengan itu keindahan sesebuah pantun perlulah dilihat menerusi kaca mata atau pandangan orang Melayu sendiri. Oleh yang demikian, prinsip dunia luas yang dipadatkan dipilih dalam kajian ini merupakan salah satu prinsip yang diperkenalkan oleh Muhammad Haji Salleh dalam memperlihatkan keindahan pantun dari kaca mata orang Melayu sendiri. Oleh sebab itulah, prinsip ini dipilih dan akan digunakan dalam menganalisis pantun untuk melihat keindahan pantun.

\section{ESTETIKA PANTUN MELAYU}

Pendekatan estetika pantun telah diperkenalkan dan dibincangkan oleh Muhammad Haji Salleh (2006) dalam bukunya Puitika Sastera Melayu. Estetika jelas menjadi sebahagian daripada pemikiran kesenian manusia Melayu yang diungkap dalam karya yang berbentuk prosa seperti hikayat mahupun karya yang berbentuk puitis seperti pantun yang menggambarkan tentang keajaiban taman, burung-burung, pantai, istana yang luas dan cantik. Keindahan itu dicari kerana berupaya membawa khalayak kepada satu tahap nikmat yang tinggi dan bayangan luar biasa yang hanya terdapat dalam karya sastera. Melalui karya indah, khalayak diberikan pengalaman yang lebih cantik dan halus daripada pengalaman seharian yang dikenali sebagai pengalaman sastera (Muhammad Haji Salleh, 2006. p. 210).

Pelbagai pengalaman yang diungkap dalam karya sastera ini, terutama pantun diperoleh dari alam hasil daripada pemerhatian yang tekun dan teliti sebagai penghuni alam. Perkara-perkara yang berlaku dalam persekitaran alam seperti pusingan waktu, perjalanan usia dan pantai yang berubah dikutip sebagai cermin makna tabiat alam raya yang dikaitkan dengan keindahan manusia. Unsur-unsur yang diperhatikan dan dikutip inilah dijadikan sebagai nilai dalam kehidupan sosial masyarakat seterusnya dipanjangkan kepada estetikanya dalam pantun (Muhammad Haji Salleh, 2006, p. 216).

Muhammad Haji Salleh telah memperkenalkan enam prinsip dalam estetika pantun, iaitu dunia luas yang dipadatkan, dunia berjodoh, kiasan dan saranan,muzik seiring kata, sesuai dan patut serta sama ukuran. Perbincangan ini hanya mengambil dan mengkaji prinsip "dunia luas yang dipadatkan" yang amat sesuai digunakan untuk menganalisis pantun.

Menurut Kamus Dewan (2005, p. 1110), padat membawa erti penuh dan rapat sekali (isinya, kandungan, susunannya). Perkataan dipadatkan membawa erti perbuatan memadatkan sesuatu ciptaan menjadi mudah dan senang. Perkara ini dapat dilihat melalui pantun yang telah dipadatkan dalam katakata yang mempunyai citra yang sangat luas. Citra ialah gambaran atau imej peribadi seseorang, barangan, organisasi dan lain-lain (Kamus Dewan, 2005, p. 283). Makna citra yang dipadatkan itu ialah hasil seni yang memungkinkan pengalaman dunia yang besar, yang mengambil jangka waktu yang panjang, pergerakan fikiran yang perlahan atau berlarutan, yang akhirnya disimpulkan hanya dalam beberapa citra, baris dan perkataan. Makna pantun disaring daripada beberapa sumber dan dalam bentuk yang kecil yang ditawarkan kepada pembaca. Citra atau kata itu sudah pun menjadi semacam penemuan 
terakhir atau kesimpulan kepada pengalaman yang sedang dibicarakan, biasanya sebagai hasil daripada suatu renungan panjang (Muhammad Haji Salleh, 2006, p. 217).

Unsur yang dipadatkan menurut Muhammad Haji Salleh (2006) adalah hasil seni yang merangkumi pengalaman dunia yang besar yang mengambil jangka masa yang panjang, pergerakan yang perlahan atau berlarutan, yang akhirnya disimpulkan dalam beberapa citra, baris dan perkataan. Dalam sesebuah pantun, makna disaring daripada beberapa sumber dan bentuk kecil yang ditawarkan kepada khalayak. Penyaringan sumber dan bentuk kecil ini merujuk kepada perkataan-perkataan yang digunakan dalam penciptaan pantun dipilih dengan tepat sesuai dengan maksud pantun yang hendak disampaikan. Citra atau kata itu sudah pun menjadi semacam penemuan terakhir atau kesimpulan kepada pengalaman yang sedang dibicarakan itu, biasanya terhasil daripada renungan yang panjang.

Cara penyusunan pantun membayangkan proses pemilihan, menurunkan dan membenarkan jaringan asosiasi antara baris-barisnya. Dua atau empat citra menggandingkan konotasi bunyi, gambar dan makna. Gandingan dua atau empat citra bercantum dalam proses saling lengkap-melengkapi, hubungmenghubungi sehinggalah muncul suatu makna dan sebutir kebijaksanaan, sebaris pelajaran yang disaring daripada peristiwa. Demikianlah juga halnya dengan citra yang diturunkan dalam baris-baris pantun. Citra yang terbaik dan disesuaikan sahaja yang dipilih untuk diletakkan ke dalam empat larik itu. Tidak harus dilupakan bahawa citra-citra ini diperhebat, dihaluskan atau dicantikkan dengan cita rasa estetik pengarang. Pengarang mengolah kembali, menyusun urutan, atau mencabut daripada kenyataan untuk disalut dengan imaginasi. Hanya yang mampu membawa yang terberat (tetapi dengan gerak yang halus) dapat diambil (Muhammad Haji Salleh, 2006, p. 217).

Makna dan citra yang dipadatkan dapat dikesan dalam pembayang dan maksud pantun yang merupakan kiasan awal untuk menggambarkan maksud dalam rangkap seterusnya. Kebanyakan kiasan ini menggunakan unsur alam terutama simbol tumbuhan dan haiwan yang mempengaruhi pemikiran masyarakat Melayu dalam penghasilan pantun. Masyarakat Melayu mempelajari alam dan perlakuan alam dalam kehidupan yang saling bergantungan kepada alam dalam meneruskan kelangsungan hidup. Perlakuan alam haiwan dipelajari melalui proses mencari rezeki seperti memburu, menangkap ikan di laut dan sungai yang memberikan pengetahuan mengenai alam haiwan. Masyarakat Melayu mengenal alam tumbuhan melalui aktiviti seharian seperti berkebun, bertani, mencari hasil hutan dan lain-lain yang mendedahkan masyarakat Melayu untuk membaca dan mentafsir perlakuan alam tumbuhan itu.

Perlakuan alam tumbuhan dibaca dan ditafsirkan oleh masyarakat Melayu untuk memahami sesuatu yang akan berlaku atau sesuatu yang telah berlaku. Perlakuan alam seperti mengetahui perasaan manusia dan menjadi tanda, memberi peringatan dan merayakan atas sesuatu kejadian atau peristiwa yang berlaku. Dalam hal ini kebijaksanaan masyarakat Melayu dipamerkan dengan penggunaan unsur atau simbol alam hasil daripada perenungan terhadap alam. Hasil perenungan terhadap alam itu, telah dipindahkan ke dalam pantun yang dijadikan simbol untuk menyampai sesuatu tujuan atau maksud hendak disampaikan yang menggambarkan kebenaran hasil daripada pemerhatian dan pemikiran masyarakat Melayu.

Apabila masyarakat Melayu membuat analogi tentang aspek-aspek kehidupan masyarakat dengan kejadian-kejadian alam, masyarakat Melayu sebenarnya membuat tafsiran tentang kejadian dan unsurunsur alam tersebut dijadikan teladan dan sempadan dalam kehidupan. Oleh yang demikian kewujudan makna yang diilhamkan daripada sesuatu sumber itu lazimnya adalah lahir dari penganalisisan khusus masyarakat terhadap alam. Dalam hal ini, masyarakat Melayu mempergunakan segala kepandaian dan kebolehan daya fikir untuk membuat sesuatu penganalisisan dan perbandingan alam dalam konteks kehidupan masyarakat (Arbaiyah Abdul Aziz, 2010, p. 535). Dengan demikian, setiap simbol tumbuhan pertanian yang diungkapkan dalam pantun mempunyai pengertian, lambang, takrif dan tamsil yang tersendiri berdasarkan pemahaman dan pengertian pemantun.

\section{ANALISIS SIMBOL TUMBUHAN PERTANIAN}

Masyarakat Melayu dahulu kebanyakannya terlibat dalam kegiatan pertanian sara diri sebagai pekerjaan dalam mencari sumber rezeki dalam kehidupan seharian. Kegiatan pertanian sara diri juga dikenali sebagai pertanian sara hidup. Dalam konteks sistem ini, hasil pertanian adalah untuk kegunaan keluarga sahaja. Oleh itu, dari aspek sistem kerja, masyarakat Melayu hanya menggunakan ahli keluarga sahaja 
dalam kegiatan pertanian ini tanpa melibatkan orang lain. Dengan kata lain, ahli keluarga merupakan pekerja dan tuan tanah pertanian tersebut. Dalam sistem ini, masyarakat tidak perlu memikirkan untuk mencari pekerja dan membayar upah kepada orang lain. Melalui cara pertanian ini, masyarakat sekadar memuaskan hati dengan keperluan bagi keluarga sahaja (Amarjit Kaur, 1991). Hal ini menggambarkan bertapa rapatnya hubungan masyarakat Melayu dengan alam tumbuhan pertanian yang dijadikan sebagai sumber rezeki.

Pengalaman hidup masyarakat Melayu sebagai petani telah memberikan idea untuk mengambil realiti alam tumbuhan pertanian dalam menghasilkan pantun. Melalui kreativiti masyarakat Melayu citra, alam tumbuhan pertanian telah digarap dalam pantun yang mewakili realiti alam, pemikiran dan pengalaman masyarakat sendiri. Hal ini menunjukkan kepekaan masyarakat terhadap tumbuhan yang dipilih sama ada dari jenis yang indah dari segi rupa dan ciri-ciri yang lain. Ciri lain yang lebih penting lagi ialah ketepatan dalam perbandingannya baik dari aspek luaran, fizikal mahupun dalaman atau spiritual. Masyarakat membuat pemilihan dari persekitaran pertanian, tumbuhan yang dipilih ialah yang diterima sebagai 'indah' oleh masyarakat bukannya yang jijik, lucah dan yang tidak menyenangkan (Harun Mat Piah, 1996, p. 139).

Perbincangan ini akan menganalisis simbol tumbuhan pertanian yang dibahagikan kepada sayursayuran dan buah-buahan. Analisis ini akan menggunakan prinsip dunia luas yang dipadatkan yang merupakan salah satu dari prinsip Puitika Sastera Melayu yang diperkenalkan oleh Muhammad Haji Salleh.

\section{Sayur-sayuran}

Sayuran boleh ditakrifkan sebagai bahagian-bahagian tumbuhan yang lembut dan sukulen seperti batang, daun, bunga, buah, ubi, rizom, umbut, rebung dan lain-lain (Ismail Saidin, 2000:1). Sayur-sayuran merupakan makanan terpenting di samping makanan utama seperti nasi atau sumber karbohidrat yang lain. Sayur memainkan peranan yang penting dalam pemakanan manusia seperti membekalkan zat makanan. Sayur kaya dengan mineral (zat galian), vitamin, protein dan karbohidrat. Selain itu, sayur sangat penting dalam peneutralan bahan-bahan berasid yang dikeluarkan ketika penghadaman daging, keju dan beberapa makanan yang lain (Institut Penyelidikan dan Kemajuan Pertanian Malaysia, 1990:1).

Sayur-sayuran dapat dibahagikan kepada dua kumpulan iaitu sayuran komersial dan sayursayuran tradisional. Sayur-sayuran komersial ialah sayuran yang ditanam mengikut kaedah-kaedah sains dan kebanyakannya telah melalui evolusi pemilihan baka, penghibridan dan telah menghasilkan berbagaibagai aneka ragam, kultivar dan hibrid sehingga sukar ditentukan keasliannya. Sayur-sayuran tradisional pula ialah sayuran yang tidak ditanam secara komersial dan kebanyakan spesies sayuran ini masih lagi dalam bentuk asli, baik spesies yang diperkenalkan dari luar negara mahupun spesies asli dalam negara. Sebahagian besar spesies ini ditanam secara perkebunan guna sendiri dan masih lagi yang tumbuh liar di hutan-hutan (Ismail Saidin, 2000:1-2). Sayur-sayuran sering ditemui dalam peribahasa, mentera dan pantun. Di dalam pantun, sayur-sayuran yang dapat ditemui seperti bayam, cekur, cendawan, halia, jagung, kacang, kangkung, keladi, kentang, labu, lada, lengkuas, timun, paku-pakis, pandan, peria, petai, petola, sawi, sengkuang, serai, temu, terung dan lain-lain.

Di dalam pantun, sayur-sayuran digunakan untuk menyampaikan sesuatu nasihat dan teguran kepada masyarakat. Contohnya,

$$
\begin{aligned}
& \text { Dari bukit turun ke kampung, } \\
& \text { Orang pintal tali saut; } \\
& \text { Pipit hendak menelan jagung, } \\
& \text { Telan tak lepas mati tersangkut. }
\end{aligned}
$$

(Pantun Melayu Bingkisan Permata, 2007, p. 1275)

Citra yang ditampilkan dari rangkap maksud pantun adalah hasil pengalaman petani yang berpengalaman dalam penanaman jagung. Pemilihan citra jagung adalah hasil renungan panjang petani dalam usaha menjaga tanaman jagung dari serangan burung iaitu burung pipit. Dalam rangkap maksud 'pipit hendak menelan jagung' menggambarkan sikap tamak seekor burung pipit yang kecil hendak menelan jagung. Simbol jagung dalam pantun merupakan lambang kepada sesuatu yang berharga yang 
menjadi rebutan ramai termasuk juga burung pipit. Burung pipit merupakan kiasan kepada golongan yang memiliki sikap tamak dalam semua hal. Sifat fizikal burung pipit yang kecil melambangkan kepada kemampuan seseorang individu yang tidak mampu menguruskan sesuatu yang lebih besar kemampuan daripada yang dimiliki oleh diri sendiri. Hal ini berlaku kerana sikap tamak yang ada dalam diri. Oleh yang demikian, dalam konteks ini pantun tersebut membawa maksud sindiran kepada individu yang memiliki sikap tamak yang diamalkan dalam kehidupan seharian.

Pantun tersebut bermaksud memberi nasihat kepada masyarakat supaya tidak memiliki sikap tamak dalam diri tetapi perlu bersikap pemurah. Pemurah dalam konteks ini bermaksud murah hati, baik hati kepada semua manusia dan makhluk, bersedia untuk membantu, bekerjasama dan menderma. Sikap pemurah dan dermawan dalam membahagikan rezeki yang diperoleh diperkatakan sebagai suatu nilai yang amat disanjung tinggi dalam masyarakat. Sebaliknya, sesiapa yang memiliki sikap tamak bukan sahaja tidak disukai dalam masyarakat tetapi turut juga mendapat amaran keras daripada Allah S.W.T. Hal ini telah dinyatakan oleh Allah dalam surah Al-Aádiyat yang bermaksud,

Sesungguhnya manusia itu sangat ingkar, tidak berterima kasih kepada Tuhannya. Dan sesungguhnya manusia itu menyaksikan (sendiri) keingkarannya. Dan sesungguhnya dia sangat bakhil karena cintanya kepada harta. Maka apakah dia tidak mengetahui apabila dibangkitkan apa yang ada di dalam kubur. Dan dilahirkan apa yang ada di dalam dada. Sesungguhnya Tuhan mereka pada hari itu Maha Mengetahui keadaan mereka.

(SurahAl-A'adiyat: 6-11)

Ayat tersebut menerangkan tentang sikap tamak seseorang kepada harta sehingga menjadi seorang yang kedekut untuk membantu orang lain. Allah sangat membenci orang yang kedekut dan akan mendapat balas di akhirat kelak. Oleh itu, sikap tamak perlulah dibuang jauh dari diri sebaliknya sikap pemurah yang perlu ditanam dalam diri individu sejak dari kecil lagi.

Selain itu, simbol jagung turut digunakan dalam pantun digunakan untuk memberikan nasihat dan teguran supaya tidak bersifat sombong dalam menjalani kehidupan dalam masyarakat. Sikap sombong adalah seperti tinggi hati, angkuh, dan bongkak. Perkara ini digambarkan melalui pantun berikut,

Berani buat berani tanggung,

Jangan suka teragak-agak;

Jangan bawa resmi jagung,

Makin berisi semakin tegak.

(Pantun Melayu Bingkisan Permata, 2007, p. 1215)

Dalam pantun tersebut, dicitrakan latar persekitaran penanaman jagung telah diambil oleh masyarakat Melayu dengan penuh halus seni pemadatannya. Citra jagung telah digunakan dalam rangkap maksud pantun iaitu 'resmi jagung' yang bermaksud sifat semula jadi jagung, iaitu merujuk kepada sifat jagung yang semakin tua semakin berdiri tegak. Dalam konteks ini, simbol jagung merupakan lambang kepada individu yang semakin kaya atau berilmu semakin sombong dengan orang lain.

Selain itu, jagung merupakan simbol kehidupan. Dalam kehidupan masyarakat tradisional orang Melayu, bertanam jagung merupakan satu usaha sampingan yang boleh mendatangkan hasil dalam masa terdekat dan amat digalakkan sementara menunggu padi masak. Ketika ini orang Melayu diajar supaya sentiasa beringat sebelum ditimpa waktu susah. Di samping itu, aktiviti penanaman jagung mampu menyuburkan tanah dan boleh dilakukan secara berkelompok terutama pada ruang-ruang tanah terbiar di samping menambah pendapatan keluarga. Keadaan ini menjelaskan bahawa jagung memberikan manfaat kepada manusia iaitu dari peringkat pucuk, ketika muda hingga jagung tua iaitu benih-benihnya pula berperanan untuk menggantikan pokok yang lama (Arbaiyah Abdul Aziz, 2010:625). Terdapat pepatah Melayu yang berbunyi 'umur baru setahun jagung' yang sering digunakan sebagai bentuk peringatan, amaran dan nasihat yang bermaksud menjelaskan masa terlalu muda dan singkat. berikut;

Selain itu, citra masyarakat Melayu petani bercucuk tanam turut digambarkan melalui pantun 


\title{
Bertanam tebu dibibir mulut, Bertanam halia di dalam hati.
}

(Pantun Melayu Bingkisan Permata, 2007, p. 580)

Pada rangkap maksud pantun tersebut, dapat dilihat citra gabungan tanaman sayur halia dengan tanaman tebu yang diusahakan oleh petani. Rangkap maksud 'bertanam tebu di bibir mulut' membawa maksud seseorang yang mengeluarkan kata-kata yang manis sama ada untuk memujuk dan sebagainya. Manakala rangkap maksud 'bertanam halia di dalam hati' membawa maksud seseorang yang mempunyai niat atau hati yang busuk. Keseluruhan maksud yang hendak disampaikan dalam pantun berikut ialah nasihat kepada masyarakat supaya berhati-hati dengan individu yang bermulut manis ketika bercakap kerana berkemungkinan di dalam hati mempunyai makna yang sebaliknya.

Pantun tersebut disampaikan sebagai satu peringat kepada masyarakat supaya berhati-hati ketika bercakap atau berbual dengan orang yang mempunyai sifat manis di mulut tetapi mempunyai hati yang busuk. Individu yang mempunyai sifat ini ketika berhadapan akan senyum dan bercakap dengan penuh kebaikan tetapi isi hatinya tidak dapat dijangka. Mengenai individu yang mempunyai sikap seperti ini ada dinyatakan oleh Rasulullah S.A.W dalam hadis yang bermaksud,

\begin{abstract}
"Akan keluar di akhir zaman lelaki yang bertaubat tipu daya dengan memakai nama agama di dunia ini. Mereka menganjurkan manusia agar berpakaian yang baik (taubat) dari bulu domba yang halus. Lidah mereka lebih manis daripada gula, sedangkan hati mereka bagaikan serigala."
\end{abstract}

(Hadith riwayat Tirmizi)

Hadis tersebut mengenai peringatan Rasulullah S.A.W kepada masyarakat bahawa pada suatu ketika akan muncul orang-orang yang mempunyai sifat munafik. Golongan ini akan menggunakan nama agama dalam mencapai matlamat yang diinginnya dengan memperdayakan orang-orang Islam itu sendiri. Contohnya, golongan ahli agama yang mengeluarkan fatwa yang berilmu dengan manis bicaranya sehingga ramai mempercayai dan menyanjungi kata-katanya. Tetapi hatinya ternyata mempunyai niat yang lain yang mengharapkan pujian dari masyarakat bukannya kerana Allah taala.

Penggunaan simbol tebu telah digunakan untuk menggambarkan kata-kata manis yang diucapkan berdasarkan rasa manis tebu. Rasa manis tebu telah dicitrakan dan dilambangkan sebagai ucapan dan kata-kata yang manis sehingga dapat menarik perhatian sesiapa yang mendengar. Manakala simbol halia telah digunakan sebagai kiasan kepada seseorang yang mempunyai hati busuk. Perkara ini adalah berdasarkan rasa pedas halia yang dicitrakan kepada sifat busuk hati yang dimiliki oleh sesetengah individu. Oleh itu, tebu melambangkan ucapan yang manis berdasarkan rasanya yang manis. Manakala halia pula merupakan kiasan kepada sifat busuk hati berdasarkan rasa pedas halia.

Selain itu, keladi yang turut tergolong dalam sayuran turut ditanam oleh masyarakat Melayu untuk kegunaan dalam masakan. Perkara ini telah dicitrakan dalam pantun berikut;

Kuning emas masaknya padi,

Mawar merah dalam jambangan;

Terima kasih daun keladi,

Budi tuan jadi kenangan.

(Pantun Melayu Bingkisan Permata, 2007, p. 118)

Pantun tersebut bermaksud menerima budi diri seseorang yang terpancar dalam rangkap maksud 'budi tuan jadi kenangan'. Pemantun telah mendapat bantuan dari seseorang yang melakukan kebaikan kepada pemantun. Sebagai tanda terima kasih pemantun telah meluahkan penghargaan melalui penciptaan pantun tersebut. Penghargaan yang dinyatakan oleh pemantun adalah budi yang telah diberikan akan dijadikan kenangan dan sentiasa diingati sepanjang hayat. Dalam konteks ini, simbol daun keladi pada rangkap maksud memberikan makna lahirnya hubungan antara individu selepas mendapat bantuan dan pertolongan yang dianggap sebagai berbudi. Hal ini adalah berdasarkan sifat keladi yang merupakan sejenis sayur yang bergetah manakala getah itu dilihat sebagai bahan untuk melekatkan atau 
mencantumkan antara dua objek. Oleh yang demikian simbol daun keladi melambang hubungan yang wujud dalam masyarakat akibat perbuatan berbudi.

Namun, dalam konteks yang lain, daun keladi mempunyai makna yang lain. Perkara ini dapat dilihat dalam peribahasa Melayu seperti 'mencurahkan air di daun keladi' yang membawa maksud orang yang tidak mahu mendengar nasihat atau tidak mengambil endah tunjuk ajar orang lain lantaran menjadi sesuatu pekerjaan itu sia-sia. Maksud ini merujuk kepada ciri-ciri daun keladi yang lazimnya tidak basah malah tidak meninggalkan kesan atau bekas apabila dicurahkan air di atasnya (Arbaiyah Ab. Aziz, 2010, p. 597). Dalam masyarakat Melayu, perkara yang amat dititikberatkan dan diberi perhatian ialah tegurmenegur terutama dalam kehidupan berkeluarga. Ibu bapa memainkan peranan penting dalam menegur dan memberikan nasihat kepada anak-anak tentang melaksanakan tanggungjawab atau ketika melakukan kesilapan supaya tidak berulang lagi. Nasihat dan teguran yang diberikan oleh ibu bapa sudah pasti ada gunanya kepada anak-anak. Justeru itu, budaya nasihat-menasihati dan tegur-menegur amat penting diteruskan dalam masyarakat.

Sayur dalam kategori ubi juga turut diungkapkan dalam pantun oleh Masyarakat Melayu iaitu ubi keledek. Ubi keledek menjadi makanan pilihan pada zaman pemerintahan Jepun di Tanah Melayu setelah bekalan beras sukar diperoleh. Pemerintahan Jepun ketika itu telah melaksanakan penyatuan beras akibat kekurangan beras di Tanah Melayu. Malah pemerintahan Jepun juga menggalakkan masyarakat Melayu melibatkan diri dalam pertanian sara diri, iaitu menanam tanaman untuk kegunaan sendiri yang cepat mengeluarkan hasil seperti ubi keledek. Simbol ubi keledektelah diungkapkan dalam pantun yang membawa makna kemiskinan seperti dalam pantun berikut;

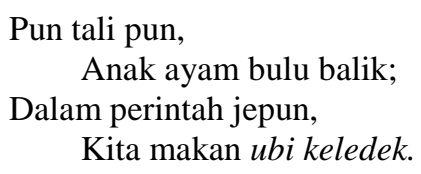

(Pantun Melayu Bingkisan Permata, 2007, p. 44)

Pantun tersebut membawa maksud kenangan masyarakat Melayu semasa dalam pemerintahan Jepun di Tanah Melayu. Pemerintahan Jepun di Tanah Melayu bermula pada tahun 1941. Kedudukan ekonomi di Tanah Melayu sangat teruk semasa pemerintahan Jepun sehingga rakyat menghadapi masalah kekurangan makanan, pakaian dan barangan keperluan harian yang lain. Untuk mengatasi masalah kekurangan makanan, pemerintahan Jepun telah menggalakkan pengeluaran makanan dengan menjalankan kegiatan sara diri (Mohamad Isa Othman, 1992:84). Demi meneruskan kelangsungan hidup, masyarakat Melayu di zaman pemerintahan Jepun mula menanam ubi keledek mengantikan makanan asasi iaitu beras. Kenangan hidup yang teruk sehingga terpaksa makan ubi keledek telah dicitrakan ke dalam pantun. Pantun ini menggambarkan citra masyarakat Melayu yang hidup semasa pemerintahan Jepun di Tanah Melayu.

Seluruh maksud pantun yang terkumpul dalam rangkap maksud terdiri daripada gabungan citra pemerintahan dan pertanian sara diri. Citra pemerintahan iaitu ketika era pemerintahan Jepun di Tanah Melayu yang menyebabkan wujudnya citra pertanian sara diri iaitu ubi keledek. Citra ini mengambarkan kesan pendudukan pemerintahan Jepun ke atas ekonomi masyarakat Melayu ketika itu yang terpaksa menamam ubi keledek sebagai makanan sampingan berlakunya catuan ke atas beras. Demi meneruskan kelangsungan hidup, masyarakat Melayu semasa pemerintahan Jepun menjadikan ubi keledek sebagai makanan untuk meneruskan kehidupan seharian. Oleh yang demikian, pantun tersebut mengambarkan citra ekonomi masyarakat Melayu ketika pemerintahan Jepun yang melaksanakan pertanian sara diri dengan menanam makanan yang cepat mengeluarkan hasil seperti ubi keledek.

\section{Buah-buahan}

Menurut Kamus Dewan (2005, p. 206), buah ialah bahagian tumbuhan yang terjadi daripada bunga atau putik (biasanya berbiji). Buah-buahan banyak ditanam kerana ia merupakan salah satu sumber makanan yang terpenting kepada manusia. Kebanyakan buah-buahan merupakan makanan tambahan kepada tubuh badan manusia, walaupun terdapat juga buah yang dijadikan makanan utama seperti sukun, pisang dan kurma. Pada zaman dahulu buah-buah tersebut menjadi sumber makanan utama di kepulauan Pasifik, di 
negara-negara Amerika Tengah dan di negara Timur Tengah. Selain ditanam untuk buah, pokok buahbuahan mempunyai nilai estetik yang tersendiri dan sering dijadikan pohon teduhan dan unsur seni taman. Banyak spesies buah-buahan mempunyai khasiat ubatan dan ada juga dimanfaatkan sebagai sayur-sayuran atau ulam (Rukayah Aman, 1999, p. xxx).

Menurut Rukayah Aman (1999: xxx-xxxi), buah-buahan merupakan sumber penting vitamin, karbohidrat, pektin dan selulosa, protein, asid amino, lemak, asid organik, enzim dan serabut. Buahbuahan yang mengandungi karbohidrat dapat dihadamkan dengan cepat, diserap oleh tubuh dan membekalkan tenaga serta haba segera sepeti buah pisang, sukun, kurma, betik, rambutan, ciku dan lainlain buah yang mempunyai kandungan gula yang tinggi. Sumber vitamin dari buah-buahan diperlukan oleh tubuh supaya sentiasa sihat dan tahan serangan penyakit. Vitamin yang terdapat dalam buah-buahan seperti Vitamin A, Vitamin C, Vitamin B, B2 dan niasin. Selain vitamin, buah-buahan membekalkan mineral seperti kalsium, magnesium, besi, fosforus, kalium, dan lain-lain yang dapat diperoleh daripada buah avokado, anggur, kurma, limau, gajus dan sebagainya. Selain itu, protein, lemak dan asid amino hanya terdapat dalam kuantiti yang kecil dalam buah-buahan segar. Manakala asid organik dalam buahbuahan membantu proses penghadaman dan menambahkan selera makan.

Dalam masyarakat Melayu, penanaman buah-buahan bertujuan untuk dijadikan sumber makanan dan sumber pendapatan. Melalui aktiviti inilah menimbulkan reaksi kreatif masyarakat Melayu yang setelah berinteraksi dengan pokok-pokok mentafsir makna daripada citra buah-buahan digunakan dalam pantun. Citra mengenai buah-buahan adalah seperti jagung, delima, peria, kelapa, beras pulut, nangka, sirih, pinang dan pisang. Contohnya;

\author{
Satu tangan bilangan lima, \\ Dua tangan bilangan sepuluh; \\ Asal ku tanam biji delima, \\ Mengapa gerangan peria yang tumbuh.
}

(Pantun Melayu Bingkisan Permata, 2007, p. 232)

Pantun tersebut membawa maksud pengharapan seseorang terhadap usaha atau rezeki yang dilakukan tetapi memperoleh lain daripada apa yang diharapkan. Rangkap maksud 'asal ku tanam biji delima' dan 'mengapa gerangan peria yang tumbuh' menggambarkan sesuatu perkara yang akan terjadi pada masa depan tidak dapat diketahui dan diramalkan. Perkara ini menunjukkan citra ini mungkin dikutip oleh seorang petani yang terlibat dalam bidang semaian biji benih ataupun penanaman pokokpokok.

Dalam konteks ini, citra biji delima dan pokok peria digunakan dalam menyampai nasihat kepada masyarakat supaya tidak mengharapkan sesuatu yang belum pasti akan berhasil pada masa depan. Oleh itu, masyarakat diingatkan supaya sentiasa berusaha dan jangan berputus asa. Selepas berusaha barulah menyerahkan segala ketentuan kepada Maha Pencipta untuk mengaturkan yang terbaik untuk masa depan. Sikap menyerah diri atau bertawakal selepas berusaha telah digambarkan melalui sabda Rasulullah S.A.W yang bermaksud,

\begin{abstract}
"Seandainya kalian bertawakal pada Allah dengan tawakal yang sebenarnya, maka sungguh Dia akan melimpahkan rezeki kepada kalian, sebagaimana Dia melimpahkan rezeki kepada burung yang pergi (mencari makan) di pagi hari dalam keadaan lapar dan kembali petang harinya dalam keadaan kenyang”.
\end{abstract}

(Riwayat Al-Tarmizi)

Pemilihan simbol biji delima menggambarkan keindahan sesuatu perkara turut digunakan dalam perumpamaan Melayu. Contohnya, untuk menggambarkan keanggunan seseorang gadis digambarkan seperti 'bibir merah bak delima merkah'. Bahkan dalam masyarakat Melayu, orang tua-tua sering berpesan kalau memakan buah delima jangan dibahagi dua. Dengan erti kata lain sebiji delima untuk seorang. Pernah juga kisah mendongengkan dengan berbuat demikian batu delima akan ditemui di dalamnya dan dipercayai batu delima itu berupaya menyembuhkan pelbagai jenis penyakit. Batu delima adalah dianggap sebagai simbol kesuburan dan kecerdikan (Arbaiyah Abdul Aziz, 2010, p. 624). 
Menurut Arbaiyah Abdul Aziz (2010, p. 628), meskipun buah peria rasanya pahit tetapi dalam budaya masyarakat Melayu ada ketikanya yang pahit itu menjadi ubat atau ulam yang paling mujarab bagi membantu mengawal dari segi kesihatan. Namun dalam konteks ini, simbol peria melambangkan sesuatu perkara yang tidak elok atau tidak diingini berdasarkan rasa pahit buah peria itu.

Gabungan simbol biji delima dan buah peria dengan jelas menunjukkan citra yang dikutip oleh seseorang petani yang sangat arif tentang setiap jenis tanaman yang ditanam. Hal ini berdasarkan hasil daripada pengalaman dan pemerhatian terhadap tumbuhan iaitu delima dan peria yang melibatkan pengalaman rasa buah dan warna buah dicitrakan ke dalam penghasilan pantun. Buah delima dan peria yang terpilih merupakan gabungan rasa buah yang pahit dan manis tetapi mempunyai khasiat masingmasing.

Di samping itu, masyarakat Melayu turut juga menggunakan simbol buah-buahan dalam pantun yang mewakili maksud tertentu. Contohnya, penggunaan simbol pisang dalam pantun berikut;

\author{
Ikan sepat lemak rasanya, \\ Lebih lemak dari gelama; \\ Pisang sesikat gulai sebelanga, \\ Tanda muafakat bersama-sama.
}

(Pantun Melayu Bingkisan Permata, 2007, p. 209)

Citra yang ditampilkan dari rangkap maksud pantun adalah hasil pengalaman petani yang berpengalaman dalam bidang penanaman pokok pisang. Pemilihan citra buah pisang hasil daripada renungan panjang petani adalah bertepatan sekali kerana buah pisang merupakan salah satu buah yang penting dalam masyarakat Melayu. Pada rangkap maksud 'pisang sesikat gulai sebelanga' menggambarkan bagaimana pisang yang hanya sesikat dapat dimasak menjadi gulai sebelanga. Simbol pisang sesikat merupakan lambang masyarakat yang hidup bekerjasama dan berganding bahu dalam melakukan sesuatu pekerjaan. Oleh itu, jelaslah bahawa pantun tersebut membawa maksud pentingnya bermuafakat dalam hidup bermasyarakat.

Bermuafakat membawa maksud berunding untuk mencapai sesuatu persetujuan ataupun bermesyuarat (Kamus Dewan, 2005, p. 1045). Bermuafakat dalam masyarakat amat penting dalam mengekalkan keharmonian dan keamanan dalam negara. Bermuafakat dalam masyarakat Melayu merujuk kepada beberapa perkara iaitu bekerjasama dalam sesuatu perkara sehingga memberikan kejayaan, masyarakat akan bersatu padu apabila bermuafakat dan kerjasama antara penduduk akan mewujudkan masyarakat yang dapat hidup aman damai. Sikap bermuafakat yang dilambangkan melalui simbol pisang adalah berdasarkan keadaan fizikal pokok pisang. Pokok pisang yang berbuah lebat kebiasaannya mempunyai beberapa sikat yang mengandungi beberapa biji pisang. Dalam konteks ini, sesikat pisang itulah merupakan kiasan kepada masyarakat yang hidup bermuafakat yang saling bergantung antara satu sama lain dalam perbincangan menghadapi sesuatu masalah. Melalui perbincangan dan kerjasama tersebutlah sesuatu masalah dapat diselesaikan dengan baik dan berjaya.

Masyarakat Melayu juga turut mengaitkan pisang dalam peribahasa iaitu 'mengenal diri bagai pisang lebat'. Pengajaran dari peribahasa ini ialah seseorang yang memiliki harta yang banyak atau kaya digesa supaya tidak memperlihatkan kekayaannya kepada orang lain. Perkara ini kerana dikhuatiri akan jatuh miskin. Orang kaya yang suka menunjuk-nunjuk kekayaannya, akan mudah menjadi mangsa sasaran orang jahat. Begitu juga kepada golongan wanita atau gadis yang suka memperagakan kecantikan akan mudah terdedah kepada mangsa perbuatan jenayah. Falsafahnya di sini ialah di sebalik kecelakaan, musibah atau kemalangan yang berlaku ada ketikanya adalah berpunca daripada perbuatan manusia itu sendiri (Arbaiyah Abdul Aziz, 2010, p. 628).

Oleh itu, simbol pisang dalam pantun sememangnya dikutip oleh petani yang sangat berpengalaman dan terlibat dalam penanaman pisang. Dalam hal ini, menunjukkan kebijaksanaan dan kepandaian petani sebagai pemantun mengaitkan pisang sebagai lambang kepada bermuafakat.

Selain itu, masyarakat Melayu turut menggunakan simbol buah kelapa dalam pantun. Contohnya;

Kalau ya selasih dani,

Pucuk sembung selera muda;

Kalau ya kasihkan kami, 
Pantun tersebut mengenai pemantun yang ingin kekasihnya membuktikan cinta melalui pencarian tombong ${ }^{1}$ kelapa muda untuknya. Di sini pemantun telah menggunakan hiperbola, iaitu kiasan yang berlebih-lebihan yang dinyatakan melalui simbol tombong kelapa muda agar mendapat perhatian dari khalayak pendengar pantun. Seperti yang sedia maklum, sebiji kelapa muda amat mustahil akan tumbuh tumbung iaitu hanya kelapa yang sudah matang atau tua sahaja akan tumbuh tumbung. Oleh itu, tujuan pemantun menggunakan simbol tumbung kelapa muda hanya untuk berlebihan-lebihan dalam menyampaikan pantun supaya menimbulkan nilai estetika yang sangat tinggi.

Selain tumbung kelapa, santan kelapa juga turut dicitrakan dalam pantun oleh masyarakat Melayu. Perkara ini dapat dilihat dalam pantun berikut;

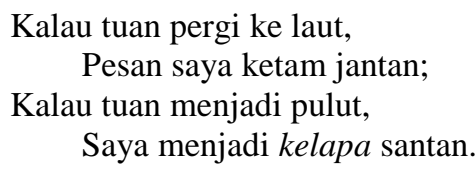

(Pantun Melayu Bingkisan Permata, 2007, p. 331)

Pantun tersebut membawa makna keinginan individu yang ingin tetap bersama dengan pasangannya dalam menjalani kehidupan. Keinginan pemantun ingin tetap bersama pasangan telah digambarkan pada rangkap maksud yang dicitrakan melalui penggunaan simbol pulut dan santan kelapa. Simbol pulut dalam pantun mewakili lelaki dan simbol santan kelapa mewakili perempuan. Hal ini kerana dalam masyarakat Melayu, pulut sering dimakan bersama dengan santan kelapa dan disertai dengan durian atau mempelam. Kedua-duanya iaitu pulut dan santan disatukan dalam pinggan melambangkan penyatuan dua hati yang sentiasa bersama-sama di dalam satu masa. Dalam konteks ini, hidangan pulut tanpa santan kelapa ibarat hidup keseorangan tanpa teman di sisi.

Citra pulut dan santan kelapa yang ditampilkan dalam rangkap maksud pantun adalah hasil pengalaman petani yang berpengalaman dalam bidang pertanian dan juga hasil pengalaman seseorang dari bidang masakan. Kedua-dua pengalaman tersebut telah disatukan dengan gabungan citra yang menarik dalam rangkap maksud dengan penuh halus dan indah menimbulkan nilai keindahan kepada pantun. Perkara ini berdasarkan keinginan hendak bersama yang diibaratkan melalui simbol pulut dan santan kelapa yang tidak dapat dipisahkan dalam masakan masyarakat Melayu.

Selain itu, simbol kelapa juga merupakan lambang kesuburan dan kemakmuran (Robiah Sidin \& Juriah Long, 1998). Hal ini dapat dilihat semasa upacara melenggang perut, kelapa digunakan melambangkan kesuburan dan kemakmuran. Kepercayaan ini mempunyai persamaan dengan kepercayaan kaum Hindu. Bahkan, menurut Arbaiyah Ab. Aziz (2010, p. 595) dalam masyarakat Melayu menanam pokok kelapa secara tradisi mengandungi erti perlambangan hidup kekeluargaan. Masyarakat Melayu dahulu mempunyai petua dalam penanaman kelapa. Orang yang hendak menanam benih kelapa hendaklah duduk bersila rapat. Mengikut kepercayaan masyarakat Melayu, dengan berbuat demikian pokok kelapa yang ditanam apabila sampai masanya akan berbuah lebat dan besar pula tandannya. Selain itu, bagi masyarakat Melayu dahulu, menanam kelapa dianggap salah satu keperluan dalam hidup berkeluarga. Hal ini kerana selain kelapa digunakan dalam masakan ia juga dikaitkan dengan adat dan kepercayaan lain. Dengan itu, boleh dilihat hampir setiap rumah masyarakat Melayu dahulu mempunyai pokok kelapa di kawasan berhampiran rumah kediaman.

Di samping itu, buah manggis juga turut diungkapkan dalam pantun. Buah manggis dapat dilihat dalam pantun berikut;

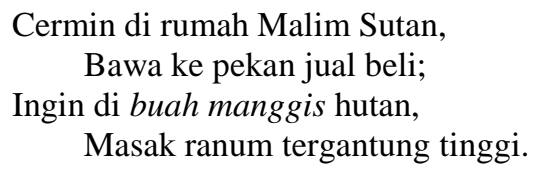

\footnotetext{
${ }^{1}$ Ejaan betul tumbung. Merujuk kepada sesuatu yang membulat dan menonjol keluar. Tumbung kelapa ialah kecambah di dalam buah kelapa (yang sudah tua) yang berwarna putih kekuningan, isinya lembut dan boleh dimakan (Kamus Dewan, 2005:1732).
} 
Pantun tersebut merupakan sindiran kepada seseorang yang tidak berdaya mendapatkan sesuatu yang susah diperoleh. Rangkap maksud 'ingin di buah manggis hutan' dan 'masak ranum tergantung tinggi' merupakan kiasan kepada seseorang yang tidak mempunyai keupayaan mendapatkan sesuatu yang susah diperoleh melebihi kemampuan diri. Dalam konteks ini, simbol buah manggis hutan yang telah masak ranum di atas pokok yang tinggi mewakili sesuatu impian atau kehendak yang sukar diperoleh tanpa usaha gigih untuk mencapai impian tersebut. Oleh itu, pantun tersebut menyarankan supaya berusaha dengan gigih dalam mencapai keinginan dan impian walaupun sukar diperoleh. Dengan usaha yang gigih dan tidak berputus asa, kemungkinan impian tersebut dapat diperoleh.

Seluruh maksud pantun yang terkumpul dalam rangkap maksud terdiri daripada gabungan pengalaman masyarakat Melayu yang berpengalaman dalam mendapatkan buah manggis hutan. Hal ini kerana masyarakat Melayu yang terlibat dalam pemburuan dan mencari hasil hutan sering mendapatkan buah-buahan di dalam hutan. Antaranya, buah manggis hutan yang sering dijadikan makanan semasa di dalam hutan. Selain simbol buah manggis, tampuk manggis juga turut dicitrakan dalam pantun. Contohnya dalam pantun berikut;

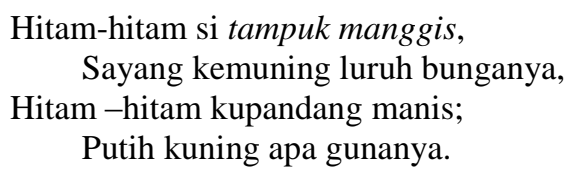

(Pantun Melayu Bingkisan Permata, 2007. p. 320)

Pantun tersebut disampaikan oleh seseorang gadis atau teruna yang sedang dilamun cinta. Tujuan penyampaian pantun untuk menyatakan perasan hati tentang rupa paras kekasih yang menjadi pujaan hatinya. Hal ini dapat dilihat pada ungkapan 'hitam-hitam si tampuk manggis' di rangkap pembayang sudah membayangkan maksud yang hendak disampaikan dalam pantun. 'Hitam-hitam si tampuk manggis' merupakan kiasan warna kulit kekasihnya yang berwarna hitam tetapi memiliki hati yang baik dan suci yang dilambangkan melalui warna putih isi buah manggis. Kemudian secara terang-terangan pada rangkap maksud dinyatakan walaupun kekasihnya berkulit hitam tetapi sedap mata memandang berbanding dengan orang yang berkulit putih.

Menurut Arbaiyah Ab. Aziz (2010, p. 615), simbol tampuk manggis melambangkan kehalusan budi pekerti, ketulusan hati, kebijaksanaan tutur bicara, beradab dan bersopan di dalam majlis, tahu bersyukur, serta membawa berkat dan kemakmuran. Malah, menerusi perumpamaan Melayu seperti 'hitam-hitam si tampuk manggis, sungguhpun hitam dipandang manis' merupakan satu nasihat yang amat berguna terutama ketika hendak menilai seseorang individu. Keelokan seseorang individu kebiasaannya terpancar di hati bukan sekadar hanya elok dari sudut luaran atau rupa paras sahaja. Oleh itu, simbol tampuk manggis dalam pantun merupakan simbolik atau kiasan kepada kebaikan hati seseorang yang tidak dinilai berdasarkan warna kulit seseorang.

Buah-buahan lain yang turut digunakan dalam pantun ialah buah kuini dan buah bacang. Buah bacang isinya berserabut dan berwarna jingga atau kuning, berbau kuat dan kulitnya licin dan berwarna hijau sehingga kuning kehijauan dengan bintik-bintik kecil berwarna perang atau hitam (Rukayah Aman, 1999:71). Buah kuini adalah buah seakan-akan buah bacang tetapi isinya lebih manis dan kurang berserabut daripada buah bacang (Rukayah Aman, 1999: 137). Pantun yang menggunakan simbol buah bacang dan kuini adalah seperti berikut;

$$
\begin{aligned}
& \text { Perahu lancing dari Patani, } \\
& \text { Naik ke darat beli kain; } \\
& \text { Buah bacang serupa kuini, } \\
& \text { Rupanya sama rasanya lain. }
\end{aligned}
$$

Pantun tersebut menyatakan tentang perangai atau sikap setiap individu adalah berlainan dan tidak sama. Rangkap maksud 'buah bacang serupa kuini' dan 'rupanya sama rasanya lain' mengambarkan seorang individu yang hampir sama luaran dengan individu yang lain tetapi mempunyai perbezaan sikap, 
perangai, perwatakan dan pendapat antara satu sama lain. Hal ini adalah berdasarkan rupa bentuk buah kuini dan bacang yang hampir sama tetapi mempunyai rasa yang berlainan. Buah kuini tekstur isinya lebih lembut, lebih padat serta lebih manis dan sedap daripada bacang. Dalam konteks ini, simbol buah kuini dan bacang mewakili bentuk luaran setiap individu yang hampir sama tetapi mempunyai pendapat, sikap, perlakuan, perasaan, kehendak dan hati berlainan antara individu.

Gambaran perumpamaan masyarakat Melayu yang mengambarkan maksud dengan pantun tersebut seperti 'rambut sama hitam, hati lain-lain'. Perumpamaan 'rambut sama hitam, hati lain-lain' merupakan satu unsur pendidikan dan nasihat yang amat berguna terutama dalam menilai seseorang individu. Dalam hal ini, setiap individu mempunyai perbezaan antara satu sama lain walaupun pada zahirnya setiap individu itu nampak sama sahaja. Namun, hakikatnya perangai dan hati setiap individu adalah berlainan dan berbeza. Oleh itu, dalam membuat keputusan mengenai sesuatu perkara janganlah dianggap setiap individu adalah sama sahaja dengan pendapat diri sendiri. Pendapat individu lain perlu juga diambil kira kerana setiap orang mempunyai perasaan dan pendapat yang berlainan.

\section{KESIMPULAN}

Masyarakat Melayu dalam menyampaikan sesuatu nasihat dan pengajaran kepada khalayakmelalui pantun yang diambil daripada simbol tumbuhan pertanian yang luas dipadatkan maksudnya dalam pantun. Simbol tumbuhan pertanian dipilih dalam penciptaan pantun adalah hasil pengalaman dan pemerhatian masyarakat Melayu yang terlibat dalam aktiviti pertanian, bercucuk tanam dan berkebun. Pemilihan simbol tumbuhan ini mempunyai kaitan secara tidak langsung dengan kehidupan masyarakat Melayu yang terlibat dalam pertanian. Setiap simbol tumbuhan yang dipilih mempunyai persamaan dengan perangai atau kelakuan manusia yang disampaikan secara kiasan dalam pantun. Hal ini menunjukkan masyarakat Melayu mempunyai hubungan yang sangat rapat dengan alam sekitar mereka terutamanya tumbuhantumbuhan.

Kesimpulannya, jelaslah masyarakat Melayu mengambil citra alam tumbuhan pertanian yang kemudiannya dipadatkan untuk memberikan sesuatu makna tersurat dan tersirat yang hendak disampaikan. Pengungkapan citra tumbuhan pertanian dalam pantun adalah berdasarkan pengalaman pemerhatian masyarakat Melayu terhadap alam yang diperolehi daripada pengalaman bertani, berkebun, mencari hasil hutan dan sebgainya. Segala perbuatan tersebut telah mewujudkan hubungan yang sangat rapat antara masyarkat Melayu dengan alam.

\section{RUJUKAN}

Al-Quran. (2007). Al-Quran dan terjemahannya. Kuala Lumpur: Pencetakan Zafar Sdn. Bhd.

Amarjit Kaur. (1991). Semenanjung Tanah Melayu abad ke-19: suatu tinjauan ekonomi dalamMasyarakat Melayu Abad Ke-19. Kuala Lumpur: Dewan Bahasa dan Pustaka.

Amat Juhari Moain. (2008). Pemilihan kata dalam pantun Melayu. Kuala Lumpur: Dewan Bahasa dan Pustaka.

Arbaiyah Abdul Aziz. (2010). Simbolisme dalam motif-motif songket Terengganu. Kuala Lumpur: Akademi Pengajian Melayu, Universiti Malaya.

Daille, F.R. (2002). Alam pantun Melayu- studies on the Malay pantun. Kuala Lumpur: Dewan Bahasa dan Pustaka.

Harun Mat Piah. (1996). Realiti dan kreativiti pantun Melayu dlm. Pantun manifestasi minda masyarakat. Selenggara oleh Wan Abdul Kadir Wan Yusoff. Kuala Lumpur: Akademi Pengajian Melayu, Universiti Malaya.

Harun Mat Piah. (2007). Pantun Melayu bingkisan permata. Kuala Lumpur: Yayasan Karyawan.

Institut Penyelidikan dan Kemajuan Pertanian Malaysia. (1990). Panduan pengeluaran sayur-sayuran. Kuala Lumpur: Institut Penyelidikan dan Kemajuan Pertanian Malaysia.

Ismail Saidin. (2000). Sayuran tradisional ulam dan penyedap rasa. Bangi: Universiti Kebangsaan Malaysia.

Kamus Dewan Edisi Keempat. (2005). Kuala Lumpur. Dewan Bahasa dan Pustaka.

Mohammad Isa Othaman. (1992). Pendudukan Jepun di Tanah Melayu 1942-1945 (Tumpuan di Negeri Kedah). Kuala Lumpur: Dewan Bahasa dan Pustaka.

Muhammad Affandi Yahya. (1995). Simbolisme dalam seni bina rumah Melayu Kelantan. Kuala Lumpur: Dewan Bahasa dan Pustaka.

Muhammad Haji Salleh. (2006). Puitika sastera Melayu. Kuala Lumpur: Dewan Bahasa dan Pustaka. Omarudin Haji Asha'ri. (1961). Kajian pantun Melayu. Singapore: Malay Publishing House Ltd. 
Robiah Sidin \& Juriah Long. (1998). Nilai budaya masyarakat desa: kajian etnografi di Kampung Tekek, Pulau Tioman, Pahang. Kuala Lumpur: Dewan Bahasa dan Pustaka.

Rukayah Aman. (1999). Buah-buahan Malaysia. Kuala Lumpur: Dewan Bahasa dan Pustaka.

Zainal Abidin Ahmad. (1965). Ilmu Mengarang Melayu. Kuala Lumpur: Dewan Bahasa dan Pustaka. 